Ann. Biol. anim. Bioch. Biophys., I976, 16 (3), 377-383.

\title{
SEXUAL MATURATION IN GIRLS AND THE DEVELOPMENT OF ESTROGEN-INDUCED GONADOTROPIC HORMONE RELEASE
}

\author{
J. PRESL, J. HOŘẼŠí, A. ŠTROUFOVÁ and J. HERZMANN \\ Institute for the Care of Mother and Child, 14710 Prague 4, \\ Department of Obstetrics and Gynecology, \\ Pediatric Faculty, Charles University, \\ Prague (Czechoslovakia)
}

\begin{abstract}
SUMMARY
During all developmental stages of female puberty $\left(\mathrm{P}_{1}-\mathrm{P}_{4}\right)$ plasma LH and FSH concentration determined by radioimmunoassay decreased after a single i.m. injection of $50 \mu \mathrm{g} / \mathrm{kg}$ estradiol-dipropionate in oil. This decrease coincidenced with the peaking level of circulating estradiol (measured by radioimmunoassay).

Only in the group of girls in an advanced stage of puberty (premenarche $P_{4}$ ) this initial nadir was followed by a secondary increase in plasma LH concentration but not in that of FSH. This secondary increase occurred during the period of decreasing level of circulating estradiol. However, only in two of the five girls at this advanced stage of puberty $\left(\mathrm{P}_{4}\right)$ the maximum of plasma LH approached the value of the preovulatory plasma LH peak in adult women. These results suggest that the potential for a stimulatory (positive) estrogen feedback response appears after midpuberty at the stage $P_{4}$.
\end{abstract}

It has been demonstrated in rats that the mechanism of the stimulatory (positive) feedback action of estrogen on gonadotropin release becomes operative at a low level of sensitivity long before estrarche. The concentration of circulating endogenous estrogen up to that time seems insufficient to trigger the release (PRESL et al., I968, I972; CALIGARIS et al., I972). In contrast, in female rhesus monkeys estrogen induced gonadotropin surges were not demonstrable until some months after menarche (DIERSchKE et al., I974). In the present study, serial determinations of plasma LH and FSH levels have been made in healthy prepubertal and pubertal girls to discover the stage of female sexual development at which the stimulatory estrogen feedback mechanism attains a level of sensitivity at which an acute increase in circulating estrogen concentration induced by a single administration of steroid is able to cause the characteristic gonadotropin release. 


\section{MATERIALS AND METHODS}

The subjects were healthy girls. Each girl's sexual maturation was graded by secondary sex characteristics only, in accordance with the following criteria (utilizing a classification of JENNER et al., 1972) : stage $P_{1}$-prepubertal (four girls), stage $P_{2}$-breast budding (mamma-areolata) and no more than sparse sexual hair (three girls), stage $P_{3}-$ mamma-areolata and moderate sexual hair (three girls), stage $P_{4}$ - mamma papillata and sexual hair which approaches the adult condition in amount and configuration (five girls), stage $P_{5}-$ postmenarcheal.

Each girl received a single intramuscular injection of $50 \mu \mathrm{g} / \mathrm{kg}$ of estradiol-dipropionate (EDP) in oil (Agofollin, Spofa).

Venous blood was obtained immediately before the injection of EDP and 24, 36, 48, 72 and 96 hours after injection, always between 9:00 and Io:oo. The plasma was stored at $-20^{\circ} \mathrm{C}$ until analysis, with all samples from each subject being assayed in duplicate in the same run.

The quantities of LH, FSH and estradiol $\left(E_{2}\right)$ in plasma samples were determined by radioimmunoassay methods using $\mathrm{KT}_{40-7002}$ (L.H) and $\mathrm{KT}_{40-300 I}$ (FSH) kits (Serono, Roma) and $\operatorname{ESTRK}\left(\mathrm{E}_{2}\right)$ kit (Sorin, Saluggia).

\section{RESULTS}

The mean plasma $\mathrm{E}_{2}$ rose steadily throughout sexual maturation (fig. I). After EDP administration, the circulating level of $\mathrm{E}_{2}$ increased abruptly, peaking at 24-36 hours following intramuscular injection (fig. 2).

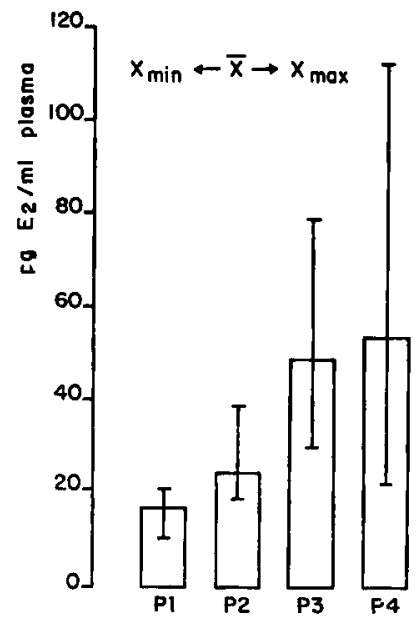

FIG. I. - Plasma estradiol concentrations (pg/ml) throughout female puberty

(means and ranges between minimum and maximum value) $\mathbf{P}_{1}-\mathbf{P}_{\mathbf{4}}$ : stages of sexual maturation

The concentration of plasma LH generally decreased following EDP administration. Only in three of four prepubertal girls $\left(P_{1}\right)$ the decline was not observed, but here the initial basal gonadotropin level was lower than $1.5 \mathrm{mIU} / \mathrm{ml}$ (fig. 3). The decrease was maximal during the period of the peak level of circulating $\mathrm{E}_{2}$ and its intensity correlated significantly $(r=0.86)$ with the initial $\mathrm{L}_{\mathbf{H}} \mathrm{H}$ concentration in the 
peripheral blood. Only in all premenarcheal girls $\left(\mathrm{P}_{4}\right)$ there appeared a marked secondary increase in plasma $\mathrm{LH}$ concentration coinciding with the decreasing level of circulating $\mathrm{E}_{2}$. This response can be shown more clearly by expressing the changes in plasma $\mathrm{LH}$ as a percentage of the initial concentration (an average increase of 483 p. IOo) (fig. 4). Only in two of the five girls at this stage of advanced puberty a plasma LH concentration was attained which resembles the preovulatory $L H$ peak in adult women (higher than $50 \mathrm{mIU} / \mathrm{ml}$ ). At the stages from $P_{1}$ up to $P_{3}$ the plasma $\mathrm{I}, \mathrm{H}$ levels just as the levels of plasma FSH oscillated irregularly after the EDP injection, (fig. 5).

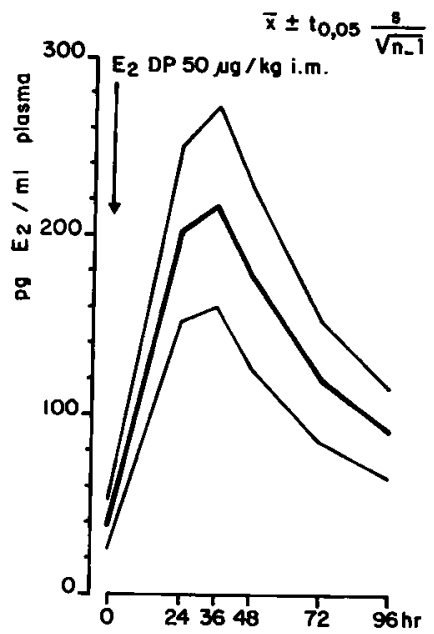

FIG. 2. - The mean plasma level of estradiol (pg/ml)

after i.m. injection of $50 \mu \mathrm{g} / \mathrm{kg}$ of estradiol-dipropionate in oil in $15 \mathrm{girls}$

The geometric means and the zone of $95 \mathrm{p}$. roo confidence limits are plotted in the figure

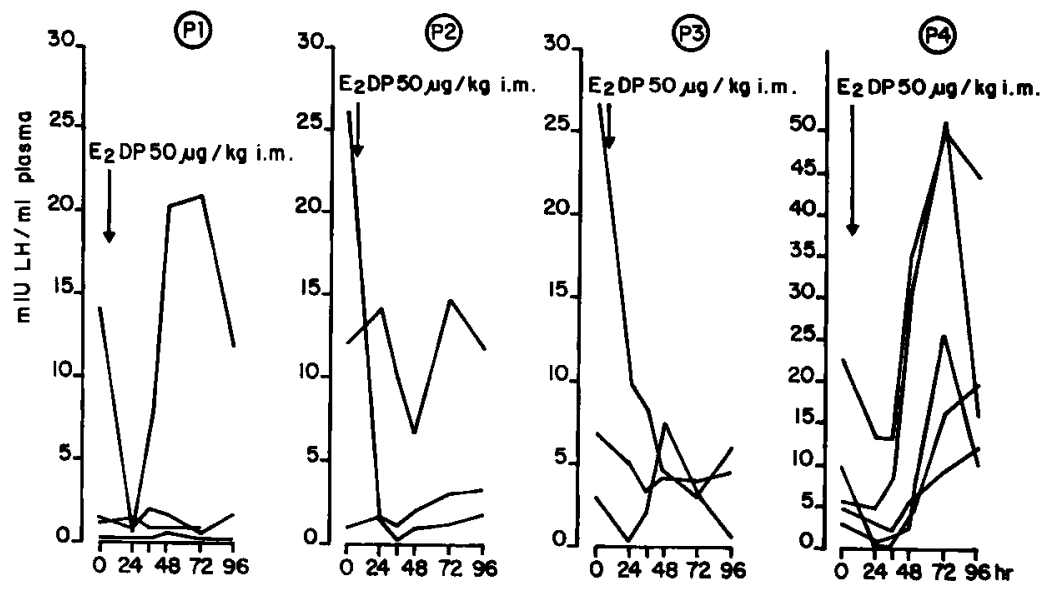

Fig. 3. - Changes in plasma LH levels (mI U/ml) after i.m. injection of $50 \mu \mathrm{g} / \mathrm{kg}$ of estradiol-dipropionate in oil in separate stages of sexual maturation in girls $\left(\mathrm{P}_{1}-\mathrm{P}_{4}\right)$ 
In premenarcheal girls $\left(\mathrm{P}_{4}\right)$, the pattern of response of plasma FSH concentration to EDP administration differed distinctly from that of $\mathrm{LH}$. A secondary increase in circulating FSH level was observed only in one of the five girls, and the difference with the initial concentration was only $+4^{0} \mathrm{p}$. Ioo (fig. 6). At all stages of sexual maturation the characteristic response was merely a decrease of plasma FSH after EDP injection.

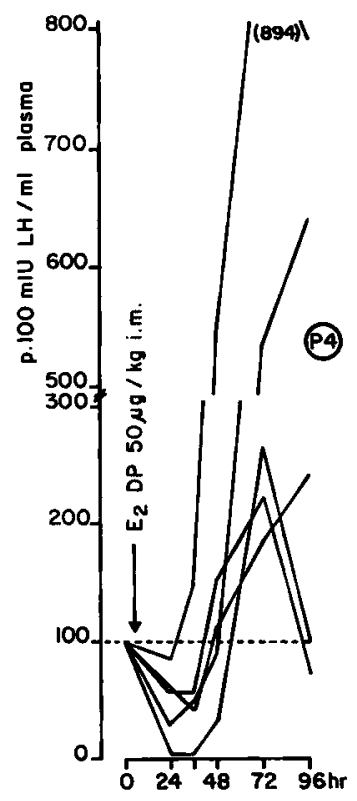

FIc. 4. - Changes in plasma LH levels (as percentages of the initial basal concentration) after estradiol-dipropionate administration in girls in advanced puberty (premenarcheal) $\left(\mathrm{P}_{4}\right)$

(P)

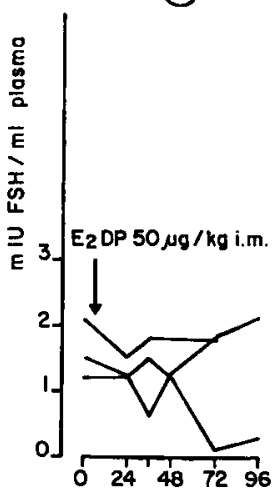

(P)

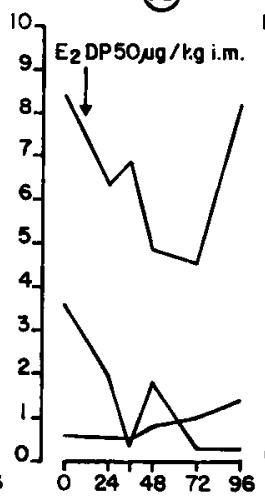

(3)

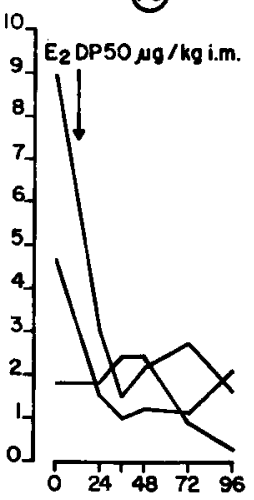

(94)

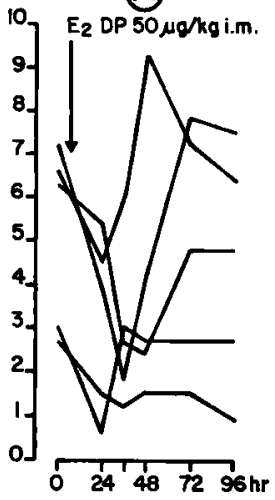

FIG. 5. - Changes in plasma FSH levels (mIU/ml) after i.m. injection of $50 \mu \mathrm{g} / \mathrm{kg}$ of estradiol-dipropionate in oil in separate stages of sexual maturation in girls $\left(\mathrm{P}_{1}-\mathrm{P}_{4}\right)$ 


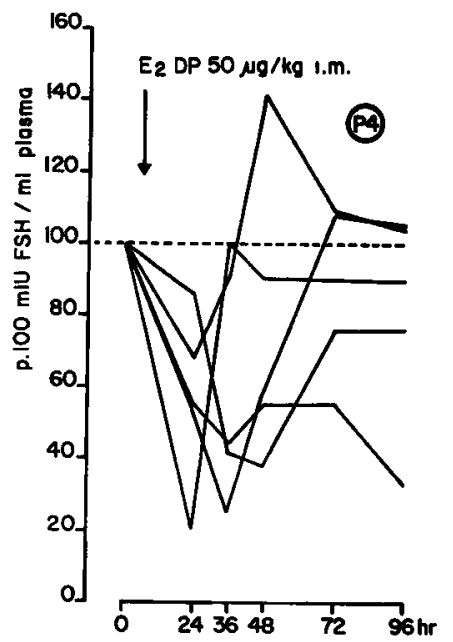

FIG. 6. - Changes in plasma FSH levels (as percentages of the initial basal concentration) after estradiol-dipropionate administration in girls in advanced puberty (premenarcheal) $\left(\mathrm{P}_{4}\right)$

\section{DISCUSSION}

An increase in circulating $E_{2}$ level paralleling sexual maturation (fig. I) agrees with the published data (JENNER et al., I972; BIDLINGMAIER et al., I973) and even our small group of girls demonstrates that the clinical classification is appropriate.

The observed primary decrease in plasma FSH and above all of plasma LH after EDP injection occurring during the period of peaking concentration of $E_{2}$ in the peripheral blood, appears to be comparable to the decrease demonstrated in adult women (NILLIUS and WIDE, I97I). Likewise the secondary increase in plasma $\mathrm{L}_{\mathrm{H}} \mathrm{H}$ in premenarcheal girls $\left(\mathrm{P}_{4}\right)$ coinciding with the decrease in circulating $\mathrm{E}_{2}$ resembles the response in adult women, just' as the absence of an increase in plasma FSH level (NILLIUS and WIDE, I97I).

The usual interpretation of the biphasic action of oestrogen upon the circulating $L_{L} H$ concentration is that the increase in plasma $E_{2}$ level inhibits $L_{1} H$ release, thereby supporting pituitary storage and, perhaps, stimulating gonadotropin synthesis too; the subsequent decrease in plasma $\mathrm{E}_{2}$ level then probably acts as a trigger for $\mathrm{L} H$ release (Yen and Tsai, I972 ; Korenman and Sherman, r973; Thompson et al., 1974). In this interpretation, the stimulatory estrogen feedback effect appears to be due to a rebound effect in a very sensitive biocybernetic system. Stored LH but not FSH is released ; it seems that estrogen acts on pituitary FSH release in a different way. This concept does not assume the existence of a separate stimulatory feedback of estrogen on $\mathrm{L} H_{H}$ release. An alternative hypothesis, considers the increased $\mathrm{L}_{\mathrm{H}} \mathrm{H}$ release to be due to a separate stimulatory estrogen feedback. This view finds support in the following observation. In ovariectomized monkeys with circulating $\mathrm{LH}$ concentration depressed by means of subcutaneously implanted silastic capsules containing 
crystalline $\mathrm{E}_{2}$, any further sudden increase in plasma $\mathrm{E}_{2}$ level after estradiol-benzoate injection induces an initial mild LH decrease and then a characteristic impressive release of $\mathrm{LH}$, evidently triggered by the preceding peak of $\mathrm{E}_{2}$ (KARSCH et al., I973a). The law of " all or nothing " does not apply here ; the circulating $\mathrm{E}_{\mathbf{2}}$ concentration must not only exceed a certain critical limit but the increase must persist during a certain period of time, which is shorter the higher the plasma $\mathrm{E}_{2}$ level (KARSCH et al., I973 b). Stimulatory estrogen feedback is thought to be independent from and superposed to the inhibitory one, mediated by a different mechanism which develops separately (for review see PRESL, I974). The presumption of this feedback as a manifestation of a mere rebound effect within a very sensitive inhibitory (negative) feedback mechanism appears to be highly improbable in the light of the present results, it emerges only in the late puberty group $\left(\mathrm{P}_{4}\right)$, but the sensitivity threshold of the inhibitory effect increases throughout sexual maturation in girls (KELCH et al., I973) and, therefore, is the highest in the late puberty group so that a resumed rebound effect should be only minimal.

Premenarcheal " maturity " of the stimulatory estrogen feedback in girls at the stage of advanced puberty $\left(\mathrm{P}_{4}\right)$ differs from that in subhuman primates : in premenarcheal monkeys, the attempts to induce an $\mathrm{LH}$ release by a single estradiolbenzoate injection failed, although $\mathrm{LH}-\mathrm{RH}$ administration was effective. Only 4-8 months after menarche, exogenous estrogen is similarly effective (YAMAJI et al., I97I ; DIERSCHKE et al., I974).

In giris ad mid- to late puberty $\left(\mathrm{P}_{3}-\mathrm{P}_{4}\right), \mathrm{LH}$ release was observed after clomiphene administration (KuLIN et al., I972). A hypothesis was expressed, therefore, that the potential for a stimulatory estrogen feedback response appears after midpuberty (KELCH et al., I973). Our present findings corroborate this concept (for review see GRUMBACH et al., 1974).

Sexual Maturation 3rd Workshop August 31, September 3, 1975.

\author{
RÉSUMÉ \\ MATURATION SEXUELLE CHEZ LA FILIETTTE ET MISE EN PLACE \\ DE LA RÉTROACTION POSITIVE DES ESTROGÈNES \\ SUR LES GONADOTROPINES
}

\begin{abstract}
A toutes les étapes du développement pubertaire de la fille $\left(\mathrm{P}_{1}-\mathrm{P}_{4}\right)$ les concentrations plasmatiques de $\mathrm{LH}$ et FSH diminuent après une injection i.m. de $50 \mu \mathrm{g} / \mathrm{kg}$ de dipropionate d'estradiol en solution huileuse. La réduction des gonadotropines coïncide avec le maximum d'estradiol circulant (dosage radioimmunologique).

Dans le groupe de filles au stade le plus avancé ( $\mathrm{P}_{4}$-préménarche) la diminution initiale des gonadotropines circulantes est suivie d'une augmentation de la concentration de la LH plasmatique mais pas de la FSH. Cette augmentation secondaire de la LH se produit quand le taux d'estradiol circulant diminue. Mais le taux maximum de LH observé n'approche les valeurs du pic préovulatoire de la Femme adulte que chez 2 sur 5 des filles au stade $P_{4}$.

Ces résultats indiquent que la possibilité d'une rétroaction positive des estrogènes apparaît après la mi-puberté, au stade $\mathbf{P}_{4}$.
\end{abstract}




\section{REFERENCES}

Bidlingmaier F., Wagner-Barnack M., Butenandt O., Knorr D., 1973. Plasma estrogens in childhood and puberty under physiologic and pathologic conditions. Pediat. Res., 9, 901-907,

Caligaris L., Astrada J. J., Taleisnik S., 1972. Influence of age on the release of LH induced by oestrogen and progesterone in immature rats. J. Endocr., 55, 97-103.

Dierschke D. J., Weiss G., Knobil E., I974. Sexual maturation in the female rhesus monkey and the development of estrogen-induced gonadotropic hormone release. Endocrinology, 94, 198-206.

Grumbach M. M., Rorh J. C., Kaplan S. L., Kelch R. P., 1974. Hypothalamic-pituitary regulation of puberty in man : Evidence and concepts derived from clinical research, II5-166, in : GrumBaCh M. M., Graye G. P., MAYeR F. E., The control of the onset of puberty, John Wiley and sons, New York.

Jenner M. R., Kelch R. P., Kaplan S. L., Grumbach M. M., I972. Hormonal changes in puberty. IV. Plasma estradiol, LH, and FSH in prepubertal children, pubertal females, and in precocious puberty, premature thelarche, hypogonadism, and in a child with a feminizing ovarian tumor. $J$. clin. Endocr., 34, 52I-530.

Karsch F. J., Dierschke D. J., Weick R. F., Yamaji T., Hotchkiss J., Knobil E., I973a. Positive and negative feedback control by estrogen of luteinizing hormone secretion in the rhesus monkey. Endocrinology, 92, 799-804.

Karsch F. J., Weick R. F., Butler W. R., Dierschke D. J., Krey L. C., Weiss G., Hotchkiss J. YaMAJI $T$., KNовIL E., I973 b. Induced LH surges in the rhesus monkey: strength-duration characteristics of the estrogen stimulus. Endocrinology, 92, 1740-1747.

Kelch R. P., Kaplay S. L., Grumbach M. M., I973. Suppression of urinary and plasma folliclestimulating hormone by exogenous estrogens in prepubertal and pubertal children. $J$. clin. Invest., 52, I122-II28.

Korenman S. G., Sherman B. M., 1973. Further studies of gonadotropin and estradiol secretion during the preovulatory phase of the human menstrual cycle. J. clin. Endocr., 36, I205-1209.

Kulin H. E., Grumbach M. M., Kaplan S. L., I972. Gonadal-hypothalamic interaction in prepubertal and pubertal man : Effect of clomiphene citrate on urinary FSH and LH and plasma testosterone. Pediat. Res., 6, I62-I71.

Nillius S. J., WIDE L., I97I. Induction of a midcycle-like peak of luteinizing hormone in young women by exogenous oestradiol-I7 $\beta$. J. Obstet. Gynaec. Brit. Cwlth., 78, 822-827.

Presl J., Horski J., KRABEC Z., I968. Development of the positive estrogen feedback in rat. Endocr. exp., 2, 161-166.

Presl J., Figarovi V., Krabec Z., Horsky J., 1972. Developmental changes in concentration of pituitary luteinizing hormone after a single estrogen injection in female rats. Endocr. exp., 6, 239-244.

Presl J., 1974. Development of the estrogen feedback. Avicenum, Zdravotnické nakladatelství, Prague (in Czech).

Thompson I. E., Karam K. S., Taymor M. L., r974. Positive feedback effects of estrogen in amenorrheic women. Amer. J. Obstet. Gynec, 118, 788-792.

Yamaji T., Dierschke D. J., Hotchkiss J., Bhattacharya A. N., Surve A. H., Knobil E., 197I. Estrogen induction of LH release in the rhesus monkey. Endocrinology, 88, 1034-104I.

YEN S. S. C., TSAI C. C., I972. Acute gonadotropin release induced by exogenous estradiol during the mid-folicular phase of the menstrual cycle. J. clin. Endocr., 34, 298-305. 